Original Article

\title{
Toll-like receptor 9 polymorphisms in brazilian patients with systemic lupus erythematosus: a pilot study
}

\author{
Polimorfismos do receptor toll-like 9 em pacientes brasileiros com lúpus eritematoso \\ sistêmico: um estudo piloto
}

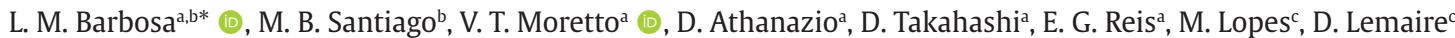 \\ and M. G. Reis ${ }^{\mathrm{a}, \mathrm{c}, \mathrm{d}}$ (D) \\ aFundação Oswaldo Cruz - FIOCRUZ, Centro de Pesquisa Gonçalo Moniz - CPqGM, Salvador, BA, Brasil \\ 'Escola Bahiana de Medicina e Saúde Pública - EBMSP, Salvador, BA, Brasil \\ 'Universidade Federal da Bahia - UFBA, Faculdade de Medicina da Bahia, Salvador, BA, Brasil \\ dYale School of Public Health, New Haven, CT, USA
}

\begin{abstract}
Toll-like receptor 9 (TLR9) is an important component of the innate immune system and have been associated with several autoimmune diseases, such as Systemic Lupus Erythematosus (SLE). The aim of this study was to investigate polymorphisms in TLR9 gene in a Brazilian SLE patients group and their association with clinical manifestation, particularly Jaccoud's arthropathy (JA). We analyzed DNA samples from 204 SLE patients, having a subgroup of them presenting JA $(n=24)$. A control group $(n=133)$ from the same city was also included. TLR9 single nucleotide polymorphisms (SNPs) $(-1237 \mathrm{C}>\mathrm{T}$ and $+2848 \mathrm{G}>\mathrm{A})$ were identified by sequencing analysis. The TLR9 gene genotype frequency was similar both in SLE patients and the control group. In the whole SLE population, an association between the homozygosis of allele $C$ at position -1237 with psychosis and anemia $(p<0.01)$ was found. Likewise, the homozygosis of allele $G$ at position +2848 was associated with a discoid rash $(p<0.05)$. There was no association between JA and TLR9 polymorphisms. These data show that TLR9 polymorphisms do not seem to be a predisposing factor for SLE in the Brazilian population, and that SNPs are not associated with JA.
\end{abstract}

Keywords: systemic lupus erythematosus, toll-like receptor 9, polymorphism, Brazilian, Jaccoud's arthropathy.

\begin{abstract}
Resumo
O receptor Toll-like 9 (TLR9) é um componente importante do sistema imunológico inato e tem sido associado a várias doenças autoimunes, como o Lúpus Eritematoso Sistêmico (LES). O objetivo deste estudo foi investigar polimorfismos no gene TLR9 em um grupo de pacientes brasileiros com LES e sua associação com a manifestação clínica, particularmente a artropatia de Jaccoud (JA). Foram analisadas amostras de DNA de 204 pacientes com LES, e um subgrupo com JA ( $n=24)$. Um grupo de controle $(n=133)$ da mesma cidade também foi incluído. Os polimorfismos de nucleotídeos únicos TLR9 (SNPs) $(-1237$ C $>$ T e +2848 G $>$ A) foram identificados pela análise de sequenciamento. A frequência do genótipo genético TLR9 foi semelhante tanto em pacientes com LES quanto no grupo controle. Em toda a população de LES, foi encontrada associação entre a homozigose do alelo C na posição -1237 com psicose e anemia $(p<0,01)$. Da mesma forma, a homozigose do alelo $G$ na posição +2848 foi associada a uma erupção cutânea discoide ( $p<0,05$ ). Não houve associação entre polimorfismos JA e TLR9. Esses dados mostram que os polimorfismos TLR9 não parecem ser um fator predisponível para o LES na população brasileira, e que os SNPs não estão associados ao JA.
\end{abstract}

Palavras-chave: lúpus eritematoso sistêmico, receptor toll-like 9, polimorfismo, brasileiro, artropatia de Jaccoud.

\section{Introduction}

Systemic lupus erythematosus (SLE) is a multisystemic autoimmune disease causing significant morbidity and mortality worldwide, particularly in women of child-bearing age. The disease is secondary to loss of self-tolerance, and is characterized by a massive production of autoantibodies against a wide range of different types of cellular and serum components (Mak and Kow, 2014; Mok and Lau, 2003). The diversity of clinical features reflects the complexity of the genetic, hormonal, and habitual factors (Lisnevskaia et al., 2014). Clinical manifestation in SLE varies from mild arthritis and cutaneous rashes to potentially fatal complications involving the central nervous

*e-mail: lucio_barbosa@hotmail.com

Received: September 30, 2020 - Accepted: January 15, 2021 
system, the kidneys, and blood vessels (Tsokos et al., 2016). Articular manifestations appear in the majority of the patients and approximately $5 \%$ of them develop a deforming arthropathy, which is well known as Jaccoud's arthropathy (JA) - the etiopathogenic mechanisms of which are not yet defined (Santiago, 2011).

Toll-like receptor 9 (TLR9) is an important component of the innate immune system that recognizes the hypomethylated cytosine-phosphate-guanine $(\mathrm{CpG})$ dideoxynucleotide motif, which is typical of bacterial and viral DNA (Ohto et al., 2015). Its activation may lead to a series of signaling events resulting in the induction of immune response and the production of interferon (Han et al., 2015). In TLR9-deficient mice the production of anti-dsDNA antibodies is inhibited (Christensen et al., 2005).

The TLR9 gene, which is located on chromosome 3p21.3, encodes approximately $5 \mathrm{~kb}$ and has 2 exons, being the second one the major coding region (Zhang et al., 2014). In 2003, Lazarus et al. (2003) demonstrated 20 different single nucleotide polymorphisms (SNPs) in this gene, but only 4 were common in the 3 different ethnic groups studied: 2 in the promoter region $(-1486 \mathrm{~T}>\mathrm{C}$ and $-1237 \mathrm{C}>\mathrm{T}), 1$ in the intron $(+1174 \mathrm{~A}>\mathrm{G})$, and 1 in the second exon $(+2848 \mathrm{G}>\mathrm{A})$; the latter was a synonymous mutation. In humans, the association between TLR9 gene polymorphisms and a predisposition for the development of SLE has been disputed. While Lee et al. (2016) suggests that TLR7, TLR8, and TLR9 polymorphisms are associated with the development of SLE in Caucasian, Asian, and African populations, and Yusuf et al. (2017) described an association between polymorphisms in the TLR9 gene and the risk for the development of SLE in Indian Tamils, other studies performed in different populations have failed to describe this association (De Jager et al., 2006; $\mathrm{Ng}$ et al., 2005). In SLE patients, TLR9 polymorphisms have being associated with some clinical features (e.g., lupus nephritis) and the presence of autoantibodies (e.g., anti-B2 glycoprotein I) (Zhou et al., 2010). Studies addressing the genetic predisposition for the development of JA in SLE are scarce but are urgently needed to investigate the intriguing question of why only a minority of SLE patients develops such a complication.

In the present study, we investigated the polymorphisms of TLR9 SNPs $(-1237 \mathrm{C}>\mathrm{T}$ and $+2848 \mathrm{~A}>\mathrm{G})$ in a group of Brazilian SLE patients and studied their association with clinical manifestations of the disease-particularly JA.

\section{Material and Methods}

\subsection{Patients}

A group of patients diagnosed with SLE based on the American College of Rheumatology criteria (Hochberg, 1997), who attended our outpatient lupus clinics in Salvador, State of Bahia, Brazil, was included in the present study. Due to its rarity, a large subgroup of SLE patients with JA-as defined by the criteria proposed by Santiago (Santiago, 2013) - was intentionally included in this study. Clinical data were obtained by interview, physical examination, and reviewing patients' records. Laboratory information was retrieved from patients' records and from new laboratory tests performed in a central lab, including blood tests with autoantibody searches and urinalysis. The study was approved by the Ethics Research Committee of our institution, and signed informed consent was obtained from every patient prior to enrollment in the study.

\subsection{Controls}

A control group composed of 133 apparently healthy individuals was used to determine the allele and genotype frequencies of the population from the city of Salvador. All participants were blood donors randomly selected from a blood transfusion center; they also signed informed consent forms.

\subsection{Single nucleotide polymorphisms $(-1237 C>T,+2848 G>A)$ of TLR9}

Genomic DNA was extracted from peripheral blood mononuclear cells using $5 \mathrm{~mL}$ of whole blood with Qiagen DNA Blood Mini kit (Valencia, CA). All SNPs were identified by sequencing fragments of the TLR9 gene amplified by the polymerase chain reaction (PCR) technique using primers described by Hur et al. (2005). Each PCR mix had approximately $50 \mathrm{ng}$ of DNA template, $25 \mathrm{uM}$ of each primer, $10 \mathrm{mM}$ of DNTPs, and $5 \mathrm{U}$ of recombinant Taq DNA polymerase (Invitrogen - Waltham, Massachusetts). For better reaction specificity, the temperature program was based on "Touch-Down" PCR variation. Thus, the temperature program consisted of: $94{ }^{\circ} \mathrm{C}$ for 3 minutes; 10 cycles of 3 steps: $94^{\circ} \mathrm{C}$ for 30 seconds, $65^{\circ} \mathrm{C}$ for position $-1237,63.5^{\circ} \mathrm{C}$ for position +2848 for 30 seconds (annealing temperature was reduced $0.5{ }^{\circ} \mathrm{C}$ at every cycle until it reached the expected annealing temperature); then $72{ }^{\circ} \mathrm{C}$ for 1 minute; 25 cycles of $94^{\circ} \mathrm{C}$ for 30 seconds, $60{ }^{\circ} \mathrm{C}$ for position $-1237,58.5^{\circ} \mathrm{C}$ for position +2848 for 30 seconds, and $72{ }^{\circ} \mathrm{C}$ for 1 minute; then the final step of $72{ }^{\circ} \mathrm{C}$ for 7 minutes.

PCR products were then purified with the spin column PCR purification kit (Qiagen, Valencia, CA). The PCR product was sequenced in both directions using primers sense and anti-sense (2 uM) using Kit ABI Prism BigDye Terminator (Applied Biosystems - Waltham, Massachusetts), following the manufacturer's instructions, and 3100 Genetic Analyzer (Applied Biosystems-Hitachi). Results were analyzed using bioinformatics software SeqScape ${ }^{\circledR} 5.1$ (Applied Biosystems-Hitachi), comparing obtained DNA sequences with reference sequence of the TLR9 gene published as NC 000003, on the National Center for Biotechnology Information website. Hardy-Weinberg equilibrium and Linkage disequilibrium were analyzed using GenePop software.

\subsection{Statistical analysis}

Statistical analysis was performed using SPSS ${ }^{\odot} 17.0$ program (Chicago, IL). In variables that showed normal distribution, the results were expressed as mean \pm standard deviation, and a Welch t-test was used to determine the differences between the groups. The association between qualitative variables was evaluated by chi-square 
corrected (Yates) or the Fisher exact test-when indicatedconsidering $\mathrm{p}<0.05$ as statistically significant.

\section{Results}

This study enrolled 204 SLE patients (24 with JA) and 133 controls. The majority of SLE patients were female (98\%) with a mean age of 40.4 years old $( \pm 12.0)$, self-declared mulatto (61.5\%), with a mean disease duration of $8.7( \pm 6.0)$ years. The subgroup with JA had a higher disease duration $(12.2 \pm 4.7$ years, $p<0.001)$ (Table 1$)$. Unfortunately, the demographic features of individuals from the control group was not provided by the blood transfusion center.

The success rate of PCR was $100 \%$ in locus -1237 ; however, locus +1174 and +2848 did not amplify for $2(1 \%)$ and $30(14.7 \%)$ of the DNA samples from the SLE patients. The overall genotype frequencies in the TLR9 gene in the SLE patients were $54.4 \%, 36.8 \%$, and $8.8 \%$ for $\mathrm{T} / \mathrm{T}, \mathrm{C} / \mathrm{T}$, and C/C, respectively, at position -1237 ; and $21.8 \%, 47.1 \%$, and $31.1 \%$ for $\mathrm{A} / \mathrm{A}, \mathrm{A} / \mathrm{G}$, and $\mathrm{G} / \mathrm{G}$, respectively, at position +2848 . For the subset of JA individuals, the genotypic frequencies

Table 1. Demographic and genetic characteristics of the SLE studied population.

\begin{tabular}{|c|c|c|}
\hline & $\begin{array}{l}\text { Entire Cohort } \\
\quad(n=204)\end{array}$ & $\begin{array}{c}\text { Jaccoud's } \\
\text { Arthropathy } \\
(\mathrm{n}=24)\end{array}$ \\
\hline Age (mean $\pm S D$ ) & $40.4(12.0)$ & $42.0(12.1)$ \\
\hline Gender (female) & $200(98.0 \%)$ & $22(95.6 \%)$ \\
\hline \multicolumn{3}{|l|}{ Self-declared race } \\
\hline Caucasian & $39(21.4 \%)$ & $5(21.7 \%)$ \\
\hline Afro descent & $28(17.0 \%)$ & $3(13.0 \%)$ \\
\hline Mulatto & $112(61.5 \%)$ & $10(65.2 \%)$ \\
\hline $\begin{array}{l}\text { Disease duration } \\
(\text { mean } \pm S D)\end{array}$ & $8.7(6.0)$ & $12.2(4.7)^{*}$ \\
\hline \multicolumn{3}{|l|}{$-1237 \mathrm{C}>\mathrm{T}^{* *}$} \\
\hline $\mathrm{T} / \mathrm{T}$ & $111(54.4)$ & $12(52.2)$ \\
\hline $\mathrm{T} / \mathrm{C}$ & $75(36.8)$ & $9(39.1)$ \\
\hline $\mathrm{C} / \mathrm{C}$ & $18(8.8)$ & $2(8.7)$ \\
\hline Total & 204 & 23 \\
\hline Allele T & 0.741 & 0.718 \\
\hline Allele C & 0.259 & 0.282 \\
\hline \multicolumn{3}{|l|}{$+2848 \mathrm{G}>\mathrm{A}^{* *}$} \\
\hline $\mathrm{A} / \mathrm{A}$ & $38(21.8)$ & $5(23.8)$ \\
\hline $\mathrm{A} / \mathrm{G}$ & $82(47.1)$ & $9(42.9)$ \\
\hline $\mathrm{G} / \mathrm{G}$ & $54(31.1)$ & $7(33.3)$ \\
\hline Total & 174 & 21 \\
\hline Allele A & 0.467 & 0.453 \\
\hline Allele G & 0.534 & 0.547 \\
\hline
\end{tabular}

${ }^{*} \mathrm{p}<0.001 ;{ }^{* *}$ Genotypes met Hardy-Weinberg expectations. SLE: systemic lupus erythematosus. SD - Standard Deviation in the TLR9 gene were $52.2 \%, 39.1 \%$, and $8.7 \%$ for $\mathrm{T} / \mathrm{T}, \mathrm{C} / \mathrm{T}$, and $C / C$, respectively, at position -1237 ; and $23.8 \%, 42.9 \%$, and $33.3 \%$ for $A / A, A / G$, and $G / G$, respectively, at position +2848 . There was no statistically significant difference in relation to the entire SLE population.

Genotype frequencies in the control group were $55.1 \%$, $39.0 \%$, and $5.9 \%$ for TT, CT, and CC, respectively, at position -1237 ; and $18.8 \%, 43.6 \%$, and $37.6 \%$ for AA, AG, and GG, respectively, at position +2848 , which was similar to the SLE patients. The distribution of genotypes for all the evaluated groups met the Hardy-Weinberg expectations. The allele frequencies in locus -1237 were 0.741 and 0.259 in SLE patients, 0.718 and 0.282 in the subgroup with JA patients, and 0.746 and 0.254 in the control group, for $\mathrm{T}$ and $\mathrm{C}$, respectively. In locus +2848 , the allele frequencies were 0.467 and 0.534 in SLE patients, 0.453 and 0.547 in JA patients, and 0.406 and 0.594 in the control group, for A and $G$, respectively, revealing no statistically significant differences among the 3 groups.

SLE patients with and without mutations in the TLR9 gene were the same regarding race, gender, age, or disease duration. A comparison of genotypes and clinical symptoms or complications revealed an association between genotype C/C at position -1237 and psychosis and hemolytic anemia $(p<0.05)$. Likewise, homozygosis of allele $G$ at position +2848 was found to be associated with the discoid rash $(\mathrm{p}<0.05)$ (Table 2).

\section{Discussion}

SLE is a multisystemic autoimmune disease-the etiology of which remains unrevealed. However, evidence shows the importance of genetic, hormonal, and habitual factors for its development (Lisnevskaia et al., 2014). TLR9 recognizes not only unmethylated $\mathrm{CpG}$-DNA sequences of prokaryotes and activates innate immune responses, but also endogenous DNA of SLE patients, making this molecule one of the potential explanations for lupus onset (Ohto et al., 2018). Based on this hypothesis, researchers have tried to identify whether genetic polymorphisms are associated with lupus susceptibility; however, they have obtained inconsistent results even though such studies were performed in populations with different genetic backgrounds (Lee et al., 2016; Yusuf et al., 2017). Using a comparison group comprised of apparently healthy blood donors, we demonstrated that polymorphisms of two genotypes for TLR-9 are not associated with SLE susceptibility in our population.

JA is a deforming arthropathy that occurs in a minority of SLE patients. Characteristically, the joint deformities are similar to those seen in rheumatoid arthritis but with a "reducible" pattern and with no erosion on plain radiograph. There is no convincing explanation for its development. Some previous studies have tried to associate JA with different autoantibodies or cytokines, and other studies with joint hypermobility, but the results have been conflicting (Franceschini et al., 1994; Nakamura et al., 2010).

The only study exploring the genetic predisposition in JA was one performed by Takeishi et al. (2001). who included a very small sample of patients with SLE and 
Table 2. Clinical features of the studied population of SLE individuals and their relationship with mutated genotypes.

\begin{tabular}{|c|c|c|c|}
\hline & \multirow[b]{2}{*}{ Entire cohort } & \multicolumn{2}{|c|}{ Mutated genotype } \\
\hline & & $\begin{array}{c}-1237(C / C) \\
(n=204)\end{array}$ & $\begin{array}{c}+2848(G / G) \\
(n=174)\end{array}$ \\
\hline Malar rash $(\mathrm{n}=204)$ & $112(55.0)$ & $8(7.1)$ & $33(33.0)$ \\
\hline Discoid rash $(n=204)$ & $41(20.1)$ & $6(14.6)$ & $17(48.6)^{*}$ \\
\hline Photosensitivity $(\mathrm{n}=204)$ & $162(79.4)$ & $14(8.6)$ & $49(34.3)$ \\
\hline Oral ulcers $(\mathrm{n}=204)$ & $73(35.8)$ & $6(8.2)$ & $22(33.3)$ \\
\hline Pleuritis $(\mathrm{n}=200)$ & $37(18.5)$ & $3(8.1)$ & $8(25.0)$ \\
\hline Pericarditis $(n=200)$ & $18(9.0)$ & $1(5.6)$ & $4(26.7)$ \\
\hline Hematuria $(\mathrm{n}=108)$ & $51(47.2)$ & $6(11.8)$ & $11(26.0)$ \\
\hline Proteinuria $(\mathrm{n}=194)$ & $50(25.8)$ & $6(12.0)$ & $10(25.6)$ \\
\hline Psychosis $(\mathrm{n}=204)$ & $21(10.3)$ & $5(23.8)^{*}$ & $6(30.0)$ \\
\hline Convulsion $(\mathrm{n}=204)$ & $14(6.9)$ & $1(7.1)$ & $3(23.1)$ \\
\hline Hemolytic anemia $(n=199)$ & $23(11.6)$ & $5(21.7)^{*}$ & $7(36.8)$ \\
\hline Leukopenia $(n=202)$ & $110(54.4)$ & $9(8.2)$ & $30(31.6)$ \\
\hline Lymphopenia $(\mathrm{n}=201)$ & $94(46.8)$ & $5(5.3)$ & $23(29.5)$ \\
\hline Thrombocytopenia $(n=200)$ & $20(10.0)$ & $1(5.0)$ & $6(30.0)$ \\
\hline Anti-Sm $(n=73)$ & $8(10.9)$ & $5(62.5)$ & $5(29.4)$ \\
\hline Anti-DNA $(\mathrm{n}=170)$ & $156(91.8)$ & $6(42.9)$ & $17(37.8)$ \\
\hline Anti-SSA ( $\mathrm{n}=89)$ & $80(89.9)$ & $3(33.3)$ & $5(22.7)$ \\
\hline
\end{tabular}

${ }^{*}$ Chi-square $-\mathrm{p}<0.05$. SLE: systemic lupus erythematosus.

JA, and demonstrated the presence of HLA-A11 and B-61 in 5 of $9 \mathrm{JA}$ patients. Herein, we found that there was no association between the polymorphisms of TLR9 and JA.

Previous studies on the association of genetic polymorphisms of TLR9 with other features of SLE have shown conflicting results (Yusuf et al., 2017; Ng et al., 2005; Shahin et al., 2016). In some animal models, deletion of the TLR9 gene inhibited the production of anti-dsDNA antibodies. In other mice models, treatment with the TLR9 agonist could trigger both anti-dsDNA antibodies and nephritis (Lafyatis and Marshak-Rothstein, 2007). In the present study, we observed the association between genotype $C / C$ at position -1237 and psychosis and hemolytic anemia ( $\mathrm{p}<0.05$ ), as well as an association between the homozygosis of allele $G$ at position +2848 and discoid rash, although we have no convincing explanation for these associations.

A potential limitation of the present study is the small sample size. Thus, the described association between the genetic profile and some features of SLE needs to be confirmed in a larger cohort of patients as well as in populations with distinct genetic backgrounds.

One strength of our study was the inclusion of a preselected large sample of JA patients, which allows us to conclude that the polymorphisms of TLR9 do not seem to be associated with this lupus arthropathy. On the other hand, these negative results do not exclude the possibility that other genetic polymorphisms have participated in the development of JA.
In conclusion, the polymorphisms of TLR9 are not associated with the development of SLE or JA in the Brazilian population.

\section{Acknowledgements}

The authors thank the Program for Technological Development in Tools for Health-PDTIS/FIOCRUZ for using its facilities. MS and MR are currently receiving a scholarship from Conselho Nacional de Desenvolvimento Científico e Tecnológico (CNPq).

\section{References}

CHRISTENSEN, S.R., KASHGARIAN, M., ALEXOPOULOU, L., FLAVELL, R.A., AKIRA, S. and SHLOMCHIK, M.J., 2005. Toll-like receptor 9 controls anti-DNA autoantibody production in murine lupus. The Journal of Experimental Medicine, vol. 202, no. 2, pp. 321331. http://dx.doi.org/10.1084/jem.20050338. PMid:16027240.

DE JAGER, P.L., RICHARDSON, A., VYSE, T.J. and RIOUX, J.D., 2006. Genetic variation in toll-like receptor 9 and susceptibility to systemic lupus erythematosus. Arthritis and Rheumatism, vol. 54, no. 4, pp. 1279-1282. http://dx.doi.org/10.1002/art.21755. PMid:16575840.

FRANCESCHINI, F., CRETTI, L., QUINZANINI, M., RIZZINI, F.L. and CATTANEO, R., 1994. Deforming arthropathy of the hands in systemic lupus erythematosus is associated with antibodies to 
SSA/Ro and to SSB/La. Lupus, vol. 3, no. 5, pp. 419-422. http:// dx.doi.org/10.1177/096120339400300510. PMid:7841997.

HAN, S., ZHUANG, H., SHUMYAK, S., YANG, L. and REEVES, W.H., 2015. Mechanisms of autoantibody production in systemic lupus erythematosus. Frontiers in Immunology, vol. 6, pp. 228. http://dx.doi.org/10.3389/fimmu.2015.00228. PMid:26029213.

HOCHBERG, M.C., 1997. Updating the American College of Rheumatology revised criteria for the classification of systemic lupus erythematosus. Arthritis and Rheumatism, vol. 40, no. 9, pp. 1725. http://dx.doi.org/10.1002/art.1780400928. PMid:9324032.

HUR, J.W., SHIN, H.D., PARK, B.L., KIM, L.H., KIM, S.Y. and BAE, S.C., 2005. Association study of Toll-like receptor 9 gene polymorphism in Korean patients with systemic lupus erythematosus. Tissue Antigens, vol. 65, no. 3, pp. 266-270. http:// dx.doi.org/10.1111/j.1399-0039.2005.00374.x. PMid:15730519.

LAFYATIS, R. and MARSHAK-ROTHSTEIN, A., 2007. Toll-like receptors and innate immune responses in systemic lupus erythematosus. Arthritis Research \& Therapy, vol. 9, no. 6, pp. 222. http://dx.doi. org/10.1186/ar2321.

LAZARUS, R., KLIMECKI, W.T., RABY, B.A., VERCELLI, D., PALMER, L.J., KWIATKOWSKI, D.J., SILVERMAN, E.K., MARTINEZ, F. and WEISS, S.T., 2003. Single-nucleotide polymorphisms in the Toll-like receptor 9 gene (TLR9): Frequencies, pairwise linkage disequilibrium, and haplotypes in three U.S. ethnic groups and exploratory case-control disease association studies. Genomics, vol. 81, no. 1, pp. 85-91. http://dx.doi.org/10.1016/ S0888-7543(02)00022-8. PMid:12573264.

LEE, Y.H., CHOI, S.J., JI, J.D. and SONG, G.G., 2016. Association between toll-like receptor polymorphisms and systemic lupus erythematosus: a meta-analysis update. Lupus, vol. 25 , no. 6 , pp. 593-601. http://dx.doi.org/10.1177/0961203315622823. PMid:26762473.

LISNEVSKAIA, L., MURPHY, G. and ISENBERG, D., 2014. Systemic lupus erythematosus. Lancet, vol. 384, no. 9957, pp. 1878-1888. http:// dx.doi.org/10.1016/S0140-6736(14)60128-8. PMid:24881804.

MAK, A. and KOW, N.Y., 2014. The pathology of T cells in systemic lupus erythematosus. Journal of Immunology Research, vol. 2014, 419029. http://dx.doi.org/10.1155/2014/419029. PMid:24864268.

MOK, C.C. and LAU, C.S., 2003. Pathogenesis of systemic lupus erythematosus. Journal of Clinical Pathology, vol. 56, no. 7, pp. 481-490. http://dx.doi.org/10.1136/jcp.56.7.481.

NAKAMURA, K., TAJIMA, Y. and TAKAI, O., 2010. Generalized laxity of connective tissue as a possible syndrome in systemic lupus erythematosus. Modern Rheumatology, vol. 20, no. 5, pp. 522-527. http://dx.doi.org/10.3109/s10165-010-0323-5. PMid:20549288.

NG, M.W., LAU, C.S., CHAN, T.M., WONG, W.H. and LAU, Y.L., 2005. Polymorphisms of the toll-like receptor 9 (TLR9) gene with systemic lupus erythematosus in Chinese. Rheumatology, vol. 44, no. 11, pp. 1456-1457. http://dx.doi.org/10.1093/rheumatology/ kei120. PMid:16188944.
OHTO, U., ISHIDA, H., SHIBATA, T., SATO, R., MIYAKE, K. and SHIMIZU, T., 2018. Toll-like receptor 9 contains two DNA binding sites that function cooperatively to promote receptor dimerization and activation. Immunity, vol. 48, no. 4, pp. 649-658.e4. http:// dx.doi.org/10.1016/j.immuni.2018.03.013. PMid:29625894.

OHTO, U., SHIBATA, T., TANJI, H., ISHIDA, H., KRAYUKHINA, E., UCHIYAMA, S., MIYAKE, K. and SHIMIZU, T., 2015. Structural basis of $\mathrm{CpG}$ and inhibitory DNA recognition by Toll-like receptor 9. Nature, vol. 520, no. 7549, pp. 702-705. http:// dx.doi.org/10.1038/nature14138. PMid:25686612.

SANTIAGO, M.B., 2013. Jaccoud's arthropathy: proper classification criteria and treatment are still needed. Rheumatology International, vol. 33, no. 11, pp. 2953-2954. http://dx.doi. org/10.1007/s00296-012-2526-X. PMid:22948542.

SANTIAGO, M.B., 2011. Miscellaneous non-inflammatory musculoskeletal conditions: Jaccoud's arthropathy. Best Practice E' Research. Clinical Rheumatology, vol. 25, no. 5, pp. 715-725. http://dx.doi.org/10.1016/j.berh.2011.10.018. PMid:22142749.

SHAHIN, R. M., EL KHATEEB, E., KHALIFA, R. H. and EL REFAI. R. M., 2016. Contribution of Toll-Like Receptor 9 Gene SingleNucleotide Polymorphism to Systemic Lupus Erythematosus in Egyptian Patients. Immunological Investigations, vol. 45, no. 3, pp. 235-242. http://dx.doi.org/10.3109/08820139.2015.1137934.

TAKEISHI, M., MIMORI, A. and SUZUKI, T., 2001. Clinical and immunological features of systemic lupus erythematosus complicated by Jaccoud's arthropathy. Modern Rheumatology, vol. 11, no. 1, pp. 47-51. http://dx.doi.org/10.3109/s101650170043. PMid:24387020.

TSOKOS, G.C., LO, M.S., REIS, P.C. and SULLIVAN, K.E., 2016. New insights into the immunopathogenesis of systemic lupus erythematosus. Nature Reviews. Rheumatology, vol. 12, no. 12, pp. 716-730. http://dx.doi.org/10.1038/nrrheum.2016.186. PMid:27872476.

YUSUF, J.H., KALIYAPERUMAL, D., JAYARAMAN, M., RAMANATHAN, G. and DEVARAJU, P., 2017. Genetic selection pressure in TLR9 gene may enforce risk for SLE in Indian Tamils. Lupus, vol. 26, no. 3, pp. 307-310. http://dx.doi.org/10.1177/0961203316659151. PMid:27432810.

ZHANG, J., ZHU, Q., MENG, F., LEI, H. and ZHAO, Y., 2014. Association study of TLR-9 polymorphisms and systemic lupus erythematosus in Northern Chinese Han population. Gene, vol. 533, no. 1, pp. 385-388. http://dx.doi.org/10.1016/j. gene.2013.08.051. PMid:24004541.

ZHOU, X.J., LV, J.C., CHENG, W.R., YU, L., ZHAO, M.H. and ZHANG, H., 2010. Association of TLR9 gene polymorphisms with lupus nephritis in a Chinese Han population. Clinical and Experimental Rheumatology, vol. 28, no. 3, pp. 397-400. PMid:20497632. 